\title{
Phytoremediation of cyanophos insecticide by Plantago major L. in water
}

\author{
Ahmed Ali Romeh
}

\begin{abstract}
Cyanophos is commonly used in Egypt to control various agricultural and horticultural pests. It is not easily hydrolyzed and thus they are highly persistent and accumulate in various aquatic compartments such as rivers and lakes. Such issues may be solved by phytoremediation, which is the use of plants for the cleanup of pollutants. Here, we tested Plantago major L. to clean water polluted with cyanophos insecticide under laboratory conditions. The biosorption capacity $\left(K_{F}\right)$ of cyanophos were 76.91, 26.18 and $21.09 \mu \mathrm{g} / \mathrm{g}$ for dry roots, fruit (seeds with shells) and leaves of the Plantago major $\mathrm{L}$., respectively. Viable Plantago major $\mathrm{L}$. in water significantly reduced cyanophos by $11.0 \% \& 94.7 \%$ during 2 hours \& 9 days of exposure as compared with $0.8 \% \& 36.9 \%$ in water without the plantain. In water with plantain, cyanophos significantly accumulated in plantain roots and leaves to reach maximum levels after two and four hours of treatment, respectively. After 1 day, the concentration of cyanophos decreased in roots and shoots until the end of testing. Three major degradation products were detected at roots and leaf samples. Here we demonstrate that plantago major L. removes efficiently cyanophos residue in water and has a potential activity for pesticide phytoremediation.
\end{abstract}

Keywords: Phytoremediation, Plantago major L, Water, Cyanophos insecticide

\section{Background}

Cyanophos (O, O-dimethyl O-4-cyanophenyl phosphorothioate) is an organophosphorus insecticide with a commercial name of Cyanox [1]. Cyanox is commonly used in Egypt to control various agricultural and horticultural insect pests such as Hemiptera of Aphididae, Coccidae, Diaspididae, Lepidoptera, etc. in various fruits and vegetables [2]. Cyanophos used in Africa to control quelea and other granivorous species that are considered pests of cereal crops [3]. Mobile ground spraying with cyanophos control quelea, as routinely practiced in Senegal during the 1995/1996 cropping season, was found to be hazardous to the environment [1]. The toxicological effect of cyanophos is the inhibition of acetylcholine esterase activity [2]. Cyanophos is not easily hydrolyzed and highly persistent and accumulate in various aquatic compartments such as rivers and lakes [4]. Desmethylcyanophos, 4-Cyanophenol and desmethyl-cyanophos oxon are degradation products of cyanophos in soil [5]. All conventional methods for the removal of pesticides

Correspondence: ahmedromeh2006@yahoo.com

Plant Production Department, Faculty of Technology and Development, Zagazig University, Zagazig, Egypt are found to be either uneconomical or insufficient [6]. Therefore, it becomes essential to search for effective and economical alternative method to overcome the constraints of convention methods. Biological method such as biosorption is an attractive and promising alternative which accumulate organic and inorganic matter including metal, dyes, phenols and pesticides and offers potential advantages such as low operating cost, minimization of chemical or biological sludge [7]. Several researchers reported on biosorption uptake of phenols, dyes and pesticides by biosorption [8].

Phytoremediation is an accumulation of plant-associated processes which include biotransformation, phytoaccumulation, phytoextraction, phytovolatilization, and rhizodegradation from enhanced microbial activity in plant rhizospheres [9] and plant transformation, conjugation, and sequestration are vital tools in waste management [10]. There have been several studies focused on the phytoremediation of pesticides $[11,12]$. Plant remediation of soils, sediments, and water is a cost-effective and resource-conservative approach for clean-up of contaminated sites [9]. Biosorption is one of the effective alternative methods for the removal of pesticides in
C Biomed Central

(c) 2014 Romeh; licensee BioMed Central Ltd. This is an open access article distributed under the terms of the Creative Commons Attribution License (http://creativecommons.org/licenses/by/2.0), which permits unrestricted use, distribution, and reproduction in any medium, provided the original work is properly cited. 
contaminated water samples. Plants can accumulate or metabolize a variety of organic compounds, including, imidacloprid [13], triazophos [14], chlorpyrifos [12,15], methyl parathion [16], and atrazine [17].

The common broad leaved plantain (Plantago major L.) is a very familiar perennial weed found anywhere by roadsides, and in meadows, cultivated fields, waste areas, and canal water. The seed and husks are in fiber expanding to become highly gelatinous when soaked in water. The methanol, ethanol and aqueous extract of Plantago major L. contained antibacterial activity against some gram negative and positive bacteria besides a weak anti-narcotic activity [18]. The encouraging results of previous studies regarding phytoremediation gained the attention of researcher to continue studies in this field. Therefore, the objective of this work was to evaluate phytoremediation by living broadleaf plantain (Plantago major L.) and non- living material from plants as cleanup methods for water contaminated with the insecticide cyanophos.

\section{Methods}

Pesticide and plant

Cyanophos (Cyanox 50\% EC) 0,0-dimethyl 0-(4-cyanophenyl) phosphorothioate was obtained from the Central Agriculture Pesticide Laboratory, Agriculture Research Center, Dokki, Gaiza, Egypt.

The common broadleaf plantain (Plantago major L.) used as seedlings in Phytoremediation experimentals and adult plants in biosorption assays from meadow-land in Zagazig University, Zagazig, Sharkia governorate, Egypt.

\section{Biosorption assays}

Raw agricultural solid wastes have been used as adsorbents. These materials are available in large quantities and may have potential as adsorbents due to their physico-chemical characteristics and low-cost [19]. So, Low cost materials (leaves, roots and fruits of Plantago major L.) have been tested for their ability to quickly sorb cyanophos. Adults Plantago major L. were collected with the help of fine jet of water causing minimum damage to the roots washed thoroughly with distilled water and blotted dry. Different plant parts separated manually to leaves, roots and fruits (seeds plus shells). The plantain leaves, roots and fruits (seeds plus shells) dried naturally on laboratory benches at room temperature $\left(28-30^{\circ} \mathrm{C}\right)$ for 5 days until crisp. Sorption was measured using $0.5 \mathrm{~g}$ of (powder) leaves, roots and fruits (seeds plus shells), each of the broad-leaved plantain in centrifuge tube was shaken with $10 \mathrm{ml}$ of the aqueous adsorbate for four hours (equilibrium concentration). Five initial concentrations $\left(C_{B}\right)$ were used in each case, ranging $1,5,10,20$ and $40 \mu \mathrm{g} / \mathrm{mL}$ plus water blank. After centrifugation at 2000 r.p.m. for 15 minutes, the concentrations of cyanophos in the supernatant (Ce) were determined. Aliquot $(4 \mathrm{~mL})$ of the supernatant was analyzed. All adsorption studies were conducted at room temperature $30^{\circ} \mathrm{C} \pm 2^{\circ} \mathrm{C}$ and three replicated were used. The amount adsorbed $(\mu \mathrm{g} / \mathrm{g})$ calculated [20]. Author aimed at plotting the adsorption isotherms due to which it is possible to compare the sorption capacity of cyanophos on different adsorbents (leaves, roots and fruits of Plantago major L.). Freundlich sorption isotherm assumes that the uptake of sorbate occurs on a heterogeneous surface by multilayer sorption and can be described by the following equation: $\mathrm{Y}=\mathrm{K}_{\mathrm{F}} \mathrm{C}_{\mathrm{e}}\left(\mathrm{n}^{-1}\right)$ where, $\mathrm{K}_{\mathrm{F}}$ is a Freundlich constant related to the adsorption capacity $(\mu \mathrm{g} / \mathrm{g})$, and $\mathrm{n}^{-1}$ is the intensity of adsorption. The values of $K_{F}$ and $n^{-1}$ can be determined from the intercept and slope, respectively of the linear plot of $\log y$ versus $\log C_{e}$. The empirical Freundlich isotherm often satisfactory model of experimental data [21].

\section{Phytoremediation assay}

Whole Plantago major L. uptake experiment was performed in nutrient solution in Erlenmeyer flasks during test period from 2 h to 9 days. A whole Plantago major L. were grown in $250 \mathrm{ml}$ of Hogland solution [22], containing $10 \mu \mathrm{g} / \mathrm{ml}$ of cyanophs in each 18 Erlenmeyer (6periods $\times 3$-replicates) flask $500 \mathrm{~mL}$. The same number of flasks with pesticide only solution $(10 \mu \mathrm{g} / \mathrm{mL})$ was prepared. Three flasks were prepared as a control with a plant alone. After 2 and 4 hours, 1, 3, 6, and 9 days, three exposed and three control plants were collected. The experiment was studied at the room temperature $\left(30 \pm 2^{\circ} \mathrm{C}\right)$. Plant roots were rinsed in running tap water for 2 minutes and were blotted dry. The plants dissected into individual leaves and roots then $4 \mathrm{~g}$ of leaves and $2 \mathrm{~g}$ of roots were analyzed for the pesticide.

\section{Residue analysis}

Water samples were extracted with methylene chloride without clean up using a continuous liquid-liquid extraction [23]. Cyanophos was extracted from the root and leaf samples with acetone or water-acetone and then extracting with petroleum ether and dichloromethane. The organic phase was separated, dried, and concentrated just to dryness [24]. The organic phase was dissolved in $5 \mathrm{~mL}$ of hexane then cleaned up via passing through a column prewashed with $50 \mathrm{ml}$ of hexane + acetone (9: $1 \mathrm{v} / \mathrm{v})$. The column was filled with acidic alumina $(5 \mathrm{~g})+$ sodium sulphate $(2 \mathrm{mg})$ and was eluate with $100 \mathrm{~mL}$ of a mixture of hexane + acetone, 9: $1 \mathrm{v} / \mathrm{v}$ [25]. The elute was evaporated to dryness and the residue was dissolved in $1.0 \mathrm{~mL}$ methanol and then analyzed by high-performance liquid chromatography (HPLC) with a UV-detector at $236 \mathrm{~nm}$. A C18 column was used, and the mobile phase was a mixture of methanol and water 
$(70: 30, \mathrm{v} / \mathrm{v})$. The flow rate was $1.0 \mathrm{~mL} / \mathrm{min}$. The retention time of cyanophos was $3.46 \mathrm{~min}$. The metabolite 4cyanophenol synthesized in our laboratory by hydrolyzing cyanophos with methanolic sodium hydroxide [5] and identified by HPLC with the same condition of cyanophos. Under these conditions, the retention time of 4cyanophenol was $1.33 \mathrm{~min}$.

\section{Data analysis}

The rate of degradation $(K)$ and half-life $\left(t_{1 / 2}\right)$ was obtained from the following Equation: The rate of degradation $(\mathrm{K})=2.303 \times$ slope. Half-life $\left(\mathrm{t}_{1 / 2}\right)=0.693 / \mathrm{K}[26]$.

In this study, all statistical analyses were performed with CoStat 6.311 CoHort Software. Significant differences between controls and contaminated samples were determined by the one-way ANOVA test.

Calibration curve was obtained by plotting peak areas in ' $y$ ' axis against concentrations of the pesticide in ' $x$ ' axis within the investigated range $(0.18$ to $12.5 \mu \mathrm{g} / \mathrm{ml})$ of concentrations. Each solution was injected in triplicate. The linearity was significant with an excellent correlation coefficient of $\mathrm{R}^{2}=0.994$. The Limit of Detection (LOD) and Quantification (LOQ) of cyanophos were evaluated using the following equations: $\mathrm{LOD}=3.3 \mathrm{~S}_{0} / \mathrm{b}$ (3) and $\mathrm{LOQ}=10 \mathrm{~S}_{0} / \mathrm{b}(4)$ [27]. Where $\mathrm{S}_{0}$ is the standard deviation of the calibration line and $b$ is the slope. The Limit of Detection LOD and Quantification LOQ of cyanophos in this study were found to be $0.34 \mu \mathrm{g} / \mathrm{mL}$ corresponding to $0.08 \mu \mathrm{g} / \mathrm{g}$ and $1.02 \mu \mathrm{g} / \mathrm{mL}$ corresponding to $0.26 \mu \mathrm{g} / \mathrm{g}$, respectively. The extraction efficiency of the analytical procedure was evaluated via recovery experiments conducted in triplicate using the fortified blank Plantago major L. samples at two different concentrations, 0.2 and $0.5 \mu \mathrm{g} / \mathrm{g}$. The average percentage recoveries obtained were between $93.1 \pm 5.3 \%, 90.9 \pm 4.5 \%$ and $88.3 \pm 3.6 \%$ in water, leaves and roots, respectively.

\section{Results and discussion Biosorption assays}

Data in Table 1 shows the biosorption capacity for cyanophos by the dry roots, fruits (seeds with shells) and leaves of Plantago major L. after four hours of exposure. The Experimental data of biosorption of cyanophos onto Plantago major $L$. showed that, the correlation coefficients $\left(\mathrm{R}^{2}\right)$ for the Freundlich isotherm were 0.971, 0.997 and 0.921 for dry roots, leaves and fruit, representing a good fit of the observed data. Dry root biosorption $K_{F}$ was much higher than that of dry fruit and dry leaves at all exposure concentrations. The amount of absorption of cyanophos can be ranked as dry roots $(76.91 \mu \mathrm{g} / \mathrm{g})$, dry fruits $(26.18 \mu \mathrm{g} / \mathrm{g})$ and dry leaves $(21.09 \mu \mathrm{g} / \mathrm{g})$. The equilibrium constant $\left(\mathrm{n}^{-1}\right)$ that related to the extent or degree of biosorption was $0.896,0.928$, and 1.04 for dry roots, dry fruit, and dry leaves of Plantago major L., respectively. The biosorption $\left(K_{\mathrm{F}}\right)$ of dry roots was 3.64 and 2.93 folds higher than that of dry leaves and dry fruit, while the $\mathrm{K}_{\mathrm{F}}$ of dry fruit was 1.24 fold larger than that of dry leaves of Plantago major L. The increase of biosorption $K_{F}$ for dry roots than dry leaves and fruits may be due to the lipid content of plant roots, in which protein, fats, nucleic acids, cellulose tissues, and other components all contain lipophilic components which appear to be more efficiency in pesticides adsorption [28]. Hetero-geneous accumulation of pesticides in different plant parts of same crop species, which could be attributed to their diverse morphological characteristics [29]. Biosorption of similar pesticides by different biomass depended on the number of sites on the biosorbent, the accessibility of the sites, the chemical state of the site (i.e., availability) and affinity between site and xenobiotic (i.e., binding strength) [30]. Also, physico-chemical parameters, such as temperature, $\mathrm{pH}$ of the contact solution and conditions of the reaction, e.g. continuous or batch mode, are reported to influence

Table 1 Biosorption of cyanophos by plantago major L. on a dry weight basis after 4 hours exposure

\begin{tabular}{|c|c|c|c|c|c|c|c|}
\hline \multirow{3}{*}{$\begin{array}{l}\text { Concentrations } \\
\text { in water } \\
(\mu \mathrm{g} / \mathrm{mL}) \pm^{*} \text { S.D. }\end{array}$} & \multicolumn{6}{|c|}{ Concentrations in water $(\mu \mathrm{g} / \mathrm{mL})$ and adsorption on a dry weight basis } & \multirow[t]{3}{*}{ Significantly } \\
\hline & \multicolumn{2}{|c|}{ Roots } & \multicolumn{2}{|c|}{ Leaves } & \multicolumn{2}{|c|}{ Fruits (seeds with shells) } & \\
\hline & $(\mu \mathrm{g} / \mathrm{mL}) \pm{ }^{*} \mathrm{~S} . \mathrm{D}$. & $(\mu g / g)$ & $(\mu \mathrm{g} / \mathrm{mL}) \pm{ }^{*} \mathrm{~S} . \mathrm{D}$. & $(\mu \mathrm{g} / \mathrm{g})$ & $(\mu \mathrm{g} / \mathrm{mL}) \pm{ }^{*} \mathrm{~S} . \mathrm{D}$. & $\overline{(\mu g / g)}$ & \\
\hline $34.07 \pm 1.0(\mathrm{a})$ & $15.17 \pm 0.67(b)$ & 2890 & $11.43 \pm 0.5(c)$ & 652.8 & $12.12 \pm 0.39(c)$ & 798.75 & $* * *$ \\
\hline $17.89 \pm 0.34$ & $8.43 \pm 0.45(b)$ & 946 & $2.23 \pm 0.13(c)$ & 313.2 & $2.50 \pm 0.23(\mathrm{c})$ & 384.75 & $* * *$ \\
\hline $9.10 \pm 0.1$ & $4.15 \pm 0.13(b)$ & 495 & $0.91 \pm 0.08(c)$ & 182.8 & $0.92 \pm 0.03(c)$ & 204.5 & *** \\
\hline $4.47 \pm 0.13$ & $2.23 \pm .05(b)$ & 224 & $0.092 \pm 0.01(c)$ & 87.56 & $0.074 \pm 0.002(c)$ & 109.9 & *** \\
\hline $0.91 \pm 0.01$ & Undetected & 90.0 & Undetected & 18.2 & Undetected & 22.8 & $* * *$ \\
\hline \multicolumn{8}{|c|}{ Freundlich parameters } \\
\hline${ }^{1} K_{f}$ & \multicolumn{2}{|l|}{76.91} & \multicolumn{2}{|c|}{21.09} & \multicolumn{3}{|c|}{26.18} \\
\hline${ }^{1 a} n^{-1}$ & \multicolumn{2}{|l|}{0.896} & \multicolumn{2}{|c|}{0.928} & \multicolumn{3}{|c|}{1.047} \\
\hline${ }^{1 b} R^{2}$ & \multicolumn{2}{|l|}{0.971} & \multicolumn{2}{|c|}{0.997} & \multicolumn{3}{|c|}{0.921} \\
\hline
\end{tabular}

${ }^{*} \mathrm{SD}$, standard deviation; ${ }^{1} \mathrm{Kf}$, adsorption capacity $(\mathrm{ug} / \mathrm{g}) ;{ }^{1 \mathrm{a}} \mathrm{n}^{-1}$, intensity of adsorption; ${ }^{1 \mathrm{~b}} \mathrm{R}^{2}$, the correlation coefficient. ${ }^{*} \mathrm{P}<0.01$, ${ }^{* * *} \mathrm{P}<0.001$. 
the adsorption results [8]. The high level of $K_{F}$ suggested that the adsorption capacity of dry roots were high [21]. Freundlich model was more appropriate to describe the adsorption characteristics of trichloroethylene (TCE) onto Carbon nanotubes [31]. The larger Freundlich constant $\mathrm{K}_{\mathrm{F}}$ showed an easy uptake of phenol from aqueous solution [32]. Agricultural fibers were more efficiency in phenol removal [33]. Furthermore, wheat ash were highly effective sorbent for herbicide MCPA [34]. Accumulation of pesticides on agricultural adsorbents is generally achieved through interactions with the hydroxyl and carboxyl groups particularly abundant in polysaccharides (cellulose and hemicelluloses) and lignin, both of which constitute about $90 \%$ of dry lignocellulosic materials [35]. The biosorption capacity $\left(\mathrm{K}_{\mathrm{F}}\right)$ of dry roots of Plantago major L. was significantly higher than that of dry leaves and dry fruits at all concentrations of imidacloprid [11]. Several researchers reported on biosorption uptake of pesticides by biosorption $[8,36]$.

\section{Uptake and distribution}

Table 2 show the phytoremediation potential of Plantago major L. to remove cyanophos insecticide from contaminated water. Viable whole plant of Plantago major L. in water solution significantly reduced cyanophos residues by $11.0 \& 94.7 \%$ during $2 \& 216$ hours of exposure periods as compared with $0.8 \& 36.9 \%$ in water solution without the plantain (Table 2$)$. The half-life value $\left(t_{1 / 2}\right)$ of cyanophos, calculated by first-order reaction, for water planted with Plantago major L. and in unplanted water was found to be 1.73 and 13.63 days, respectively (Table 2). These data demonstrated that, most of the cyanophos disappearance by a Plantago major L. may be attributed to the uptake potential and transformation or degradation by the enzyme induction capability of the plant or by microorganisms in the plant root zone. Only one of them contributes to the reduction of a contaminant or connected them [37]. The growing cells of short-rod gram-negative bacteria that isolated from the water solution containing Plantago major L. was able to induce $93.34 \%$ loss of imidacloprid as a source of both carbon and nitrogen within a short period (48 hrs) compared with $31.90 \%$ in un inoculated medium [11]. The $t_{1 / 2}$ value of cyanophos for Nile water was found to be 7 days [38]. Under illumination, the halflife was estimated to be 2 and 4 days on soil and silica, respectively, while it was evaluated to be $120 \mathrm{~min}$ in acetone solution [39]. Viable whole Plantago major L. in water solution reduced imidacloprid residues by $55.81-95.17 \%$, during 1-10 days of exposure periods compared with 13.71-61.95\% in water solution without Plantago major L. [11]. The disappearance rate constant $\left(k_{r}\right)$ is 8.0 times greater in water solution with plantain than in the cyanophos control. The areas under the curve (AUC) represent compound concentration during the period of study. AUC in the water solution with plantain was decreased than cyanophos control (Table 2).

In water, cyanophos uptake and distribution by both roots and leaves of Plantago major L. are shown in the Table 2. Cyanophos was taken up by roots much faster than shoots. In water, Cyanophos significantly accumulated in the roots of Plantago major L. to reach the maximum levels after $2 \mathrm{hrs}(243.5 \pm 1.32 \mu \mathrm{g} / \mathrm{g})$. Afterwards

Table 2 Concentrations of cyanophs uptake during plantago major $\mathbf{L}$

\begin{tabular}{|c|c|c|c|c|c|c|c|c|c|}
\hline \multirow[t]{2}{*}{ Determinations } & \multirow[t]{2}{*}{2 hours } & \multicolumn{8}{|c|}{ Days after application } \\
\hline & & 0.17 & 1 & 3 & 6 & 9 & $\begin{array}{l}{ }^{1} t_{1 / 2} \\
\left(D^{-1}\right)\end{array}$ & $\begin{array}{l}{ }^{2} \mathrm{~K}_{\mathrm{r}} \\
\left(\text { Dayy }^{-1}\right)\end{array}$ & $\begin{array}{l}{ }^{3} \text { AUCmg I } \\
\left(\text { Day }^{-1}\right)\end{array}$ \\
\hline \multicolumn{10}{|l|}{ In water solution } \\
\hline$\mu \mathrm{g} / \mathrm{mL} \pm{ }^{*} \mathrm{~S} . \mathrm{D}$ & $9.92 \pm 0.14 a$ & $9.85 \pm 0.1 \mathrm{a}$ & $9.20 \pm 0.21 \mathrm{a}$ & $8.59 \pm 0.12 a$ & $7.19 \pm 0.17 \mathrm{a}$ & $6.31 \pm 0.1 \mathrm{a}$ & 13.63 & 0.05 & 71.37 \\
\hline$\%$ loss & 0.8 & 1.5 & 8.0 & 14.1 & 28.1 & 36.9 & & & \\
\hline \multicolumn{10}{|c|}{ In water solution with plantain } \\
\hline$\mu \mathrm{g} / \mathrm{mL} \pm{ }^{*} \mathrm{~S} . \mathrm{D}$ & $8.55 \pm 0.11 c$ & $7.70 \pm 0.10 c$ & $4.53 \pm 0.1 c$ & $2.89 \pm 0.03 c$ & $1.13 \pm 0.03$ & $0.53 \pm 0.02 c$ & 1.73 & 0.40 & 20.13 \\
\hline$\%$ loss & 11.0 & 23.0 & 54.7 & 71.1 & 88.7 & 94.7 & & & \\
\hline Significantly & $* * *$ & $* * *$ & $* * *$ & $* * *$ & $* * *$ & $* * *$ & & & \\
\hline \multicolumn{10}{|l|}{ In plantain roots } \\
\hline$\mu \mathrm{g} / \mathrm{g} \pm \mathrm{S} . \mathrm{D}$ & $243.5 \pm 1.32 \mathrm{a}$ & $113.49 \pm 1.56 a$ & $56.25 \pm 1.13 a$ & $49.21 \pm 1.24 a$ & $45.26 \pm 1.25 a$ & $42.11 \pm 1.35 a$ & & & \\
\hline \multicolumn{10}{|l|}{ In plantain leaves } \\
\hline$\mu \mathrm{g} / \mathrm{g} \pm{ }^{*} \mathrm{~S} . \mathrm{D}$ & $53.63 \pm 0.87 b$ & $73.0 \pm 1.04 b$ & $40.29 \pm 0.67 b$ & $36.4 \pm 0.86 b$ & $31.62 \pm 0.71 b$ & $20.00 \pm 1.0 b$ & & & \\
\hline Total uptake & 297.13 & 186.49 & 96.54 & 85.64 & 76.88 & 30.0 & & & \\
\hline Significantly & $* * *$ & $* * *$ & $* * *$ & $* * *$ & $* * *$ & $* * *$ & & & \\
\hline
\end{tabular}

${ }^{1} \mathrm{~T}_{1 / 2}$, half-life; ${ }^{2} \mathrm{kr}$, disappearance rate constant; ${ }^{3} \mathrm{AUCS}$, areas under the curve represent compound concentration during the period of study; ${ }^{*} \mathrm{SD}$, standard deviation

${ }^{*} \mathrm{P} \pm 0.01,{ }^{* * *} \mathrm{P} \pm 0.001$. 


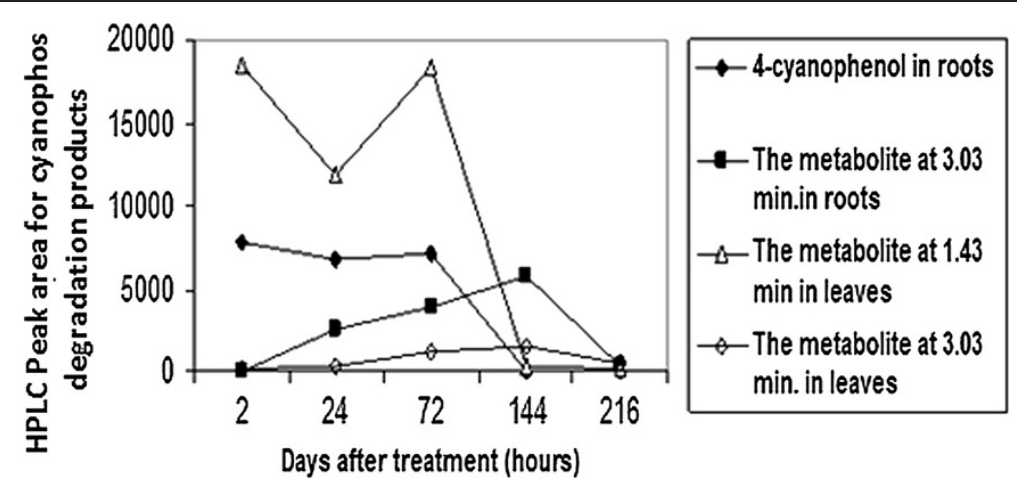

Figure 1 Uptake of cyanophos degradation products in water by Plantago major L. roots and leaves.
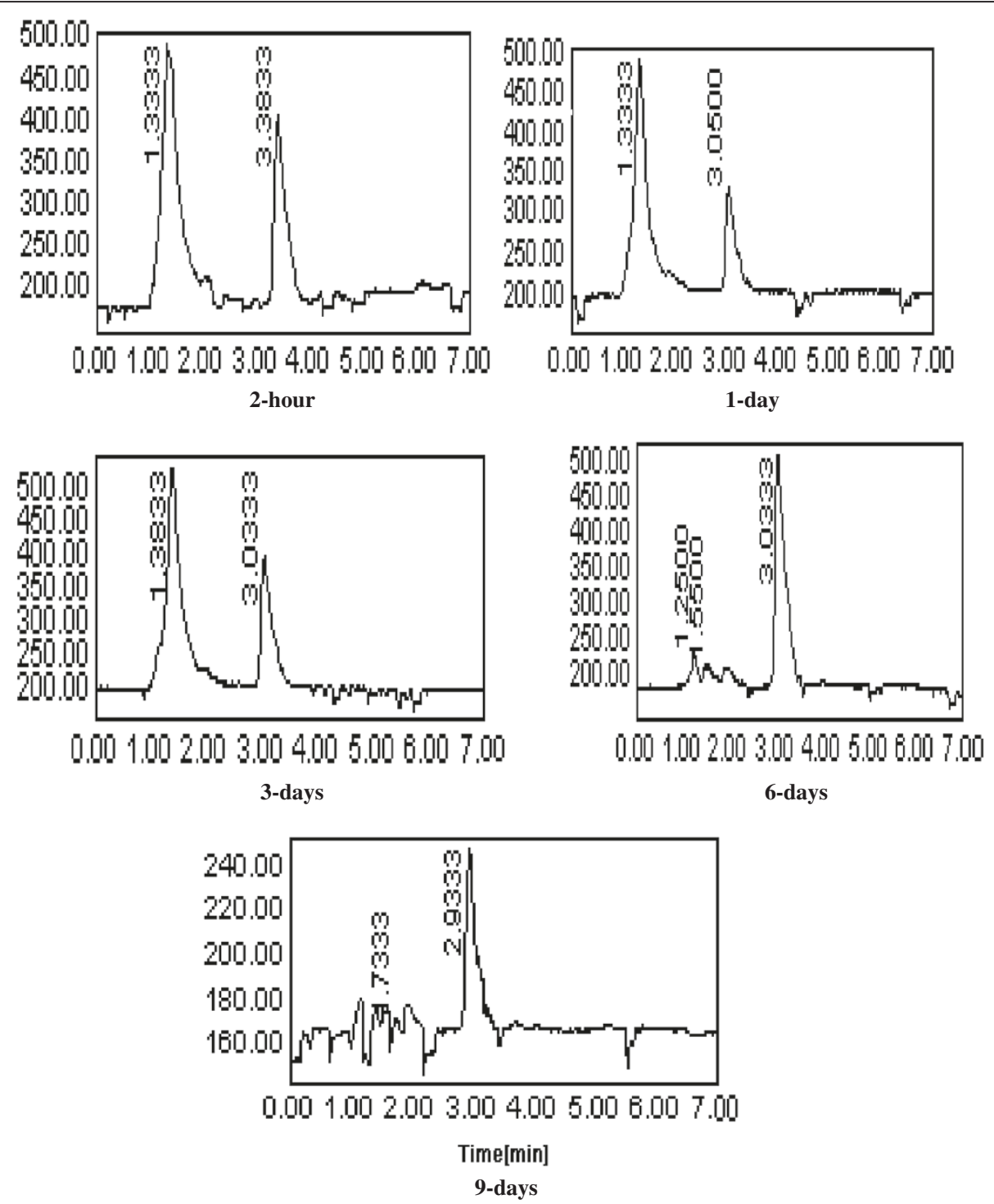

Figure 2 HPLC Chromatogram of cyanophos and its degradation products in water by Plantago major L. roots. Note, Retention time (R.T) of cyanophos and its degradation product 4-cyano phenol were 3.38 and $1.33 \mathrm{~min}$, respectively. 
concentration decrease gradually throughout the test. Cyanophos translocated into the leaves $(53.63 \pm 0.87 \mu \mathrm{g} / \mathrm{g})$ within $2 \mathrm{hrs}$ and reached the maximum after 0.17 day of exposure $(73.0 \pm 1.04 \mu \mathrm{g} / \mathrm{g})$, then decreased until the end of testing (Table 2). It has been observed that roots were important in accumulating compounds due to their direct exposure of toxic chemicals with underground parts, and transporting the compounds to above-ground organs (shoots) [40]. The uptake and translocation of organic compounds are dependent on hydrophobicity (lipophilicity), solubility, polarity, molecular weight, plant species and environmental factors [41]. Lipophilicity is the most important property of a chemical in determining its movement into and within a plant and is related to the n-octanol/ water partition coefficient $\left(\mathrm{K}_{\mathrm{ow}}\right)$ value. For uptake, $\log \mathrm{K}_{\mathrm{ow}}$ must be typically between 0.5 and 3.0. Compounds with larger $\log \mathrm{K}_{\mathrm{ow}}$ are hydrophobic and may adsorb strongly onto roots. With smaller $\log \mathrm{K}_{\mathrm{ow}}$ are too hydrophilic to pass through cell membrane [42]. Cyanophos is a moderately hydrophobic compound ( $\left.\log \mathrm{K}_{\mathrm{ow}} 2.65\right)$ and is likely to partially adsorb onto roots or be taken up by roots and move across cell membranes to reach the aboveground portion of plants. Foliar uptake directly into the aboveground portion of plants is an important route compared with root uptake, especially for volatile and semi-volatile compounds [43]. However, the volatility of cyanophos was found to be substantially high, V.p. 105 at $20^{\circ} \mathrm{C}$ [2] therefore, cyanophos residue accumulated in the roots and moved to the aerial part of the plant material. Also, potential uptakes of organic contamination are influenced by evapotranspiration [44]. Pesticide remediation is enhanced in emergent and floating vegetation by high
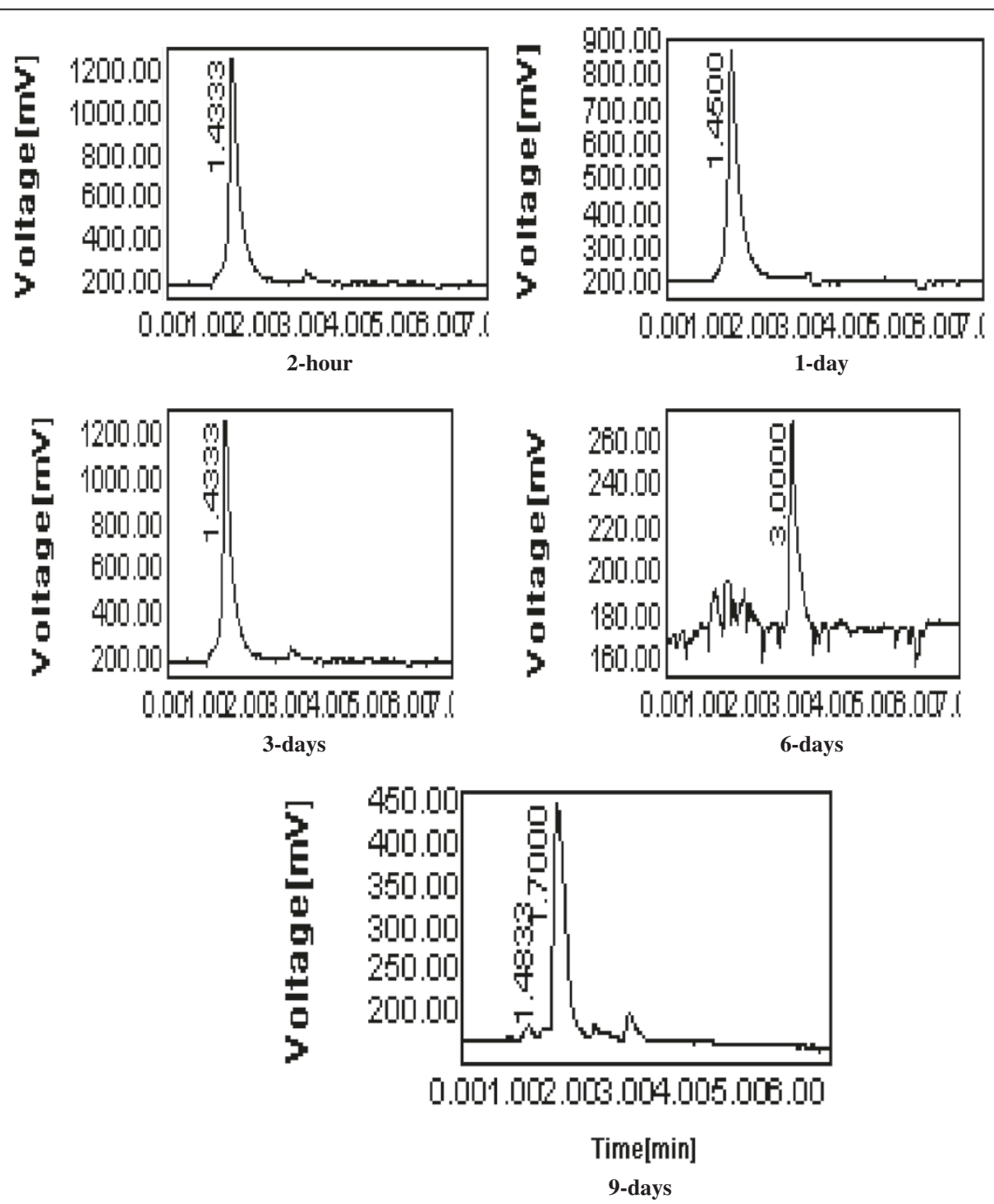

Figure 3 HPLC Chromatogram of cyanophos and its products in water by Plantago major L. leaves. 
transpiration rates and lipids associated with plant cuticles [44], therefore higher transpiration rates of emergent vegetation could be expected to increase volatilization of pesticide metabolites resulting in greater remediation capabilities. Most of the transport of pesticides occurs in aquatic plants via rhizomes. Once moved inside the plants, pesticides are acropetally distributed from the roots primarily into the leaves and lost via diffusion if volatile [45]. The rooted portion of Acorus. gramineus plays an import role in the total pesticide-uptake due to the relatively high weight-based accumulation of pesticides and its contribution to organ biomass proportion [46]. Among the organophosphorus pesticide, malathion was an efficient accumulator ( $81 \%$ ) in the roots, followed by fenitrothion (76\%), diazinon (65\%), and parathion (64\%), respectively. In water solution with Plantago major L., imidacloprid significantly accumulated in plantain roots, leaves and fruits to reach the maximum levels after 6, 1 and 3 days of treatment, respectively. The maximum levels were $15.74,37.21$, and $5.74 \mu \mathrm{g} / \mathrm{g}$, respectively. These values were decreased to $6.95,1.46$, and $0.12 \mu \mathrm{g} / \mathrm{g}$ after 10 days of treatment [11]. Plants can accumulate or metabolize a variety of organic compounds, including, imidacloprid [13], triazophos [14], chlorpyrifos [12,15], methyl parathion [16] and atrazine [17,47]. Several grass species were utilized to create grass waterways and buffer strips to contain polluted surface waters [48-50]. The disappearance of cyanophos was coupled with the appearance of the metabolites in the roots and the leaves of Plantago major $\mathrm{L}$. Three major degradation products were detected at roots and leaf samples (Figures 1, 2 and 3). Two major metabolites 4-cyanophenol and product with retention time (R.T.) of 1.43 minutes were detected in roots and leaves, respectively. One other metabolite was detected in both roots and leaves at a R.T. of 3.05 minutes (Figures 1 and 2). In the water solution, the degradation products 4-cyanophenol and the product at a R.T. of 1.43 minutes were detected in the roots and the leaves after two hours, respectively. After1 day, the product at a R.T. of 1.43 minutes was decreased gradually in leaves until the end of sampling while the 4-cyanophenol was no detectable in roots at 6 days (Figures 1 and 2). The metabolite at a R.T. of 3.05 minutes was detected in both roots and leaves after 1 day and 2 hours, respectively. The metabolite at a R.T. of 3.05 minutes increased gradually to 6 days then decreased throughout the 9 days of exposure (Figure 1). These data indicated that Plantago major L., degrade cyanophos enzymatically in water. Cyanophos was taken up rapidly and metabolized by the root of bean in hydroponic solution [5]. After 9 days, 24\% remained as unchanged and $24 \%$ as desmethyl-cyanophos via demethylation. The important metabolite 4-cyanophenol a probably occurs principally by the hydrolysis of Oxon in plants. The same author found that when cyanophos was applid to bean leaves cyanophos oxon and desmethylcyanophos oxon were also detected. The aerobic metabolism of cyanophos in water-sediment systems undergoes the cleavage of the $\mathrm{P}-\mathrm{O}$-methyl and $\mathrm{P}-\mathrm{O}$-aryl bonds together with the oxidation of the $\mathrm{P}=\mathrm{S}$ to the oxon group and the hydrolysis of the cyanophos moiety [51]. Photooxidation reaction leading to the formation of the oxon derivative and the scission of the $\mathrm{P}-\mathrm{O}$ bond generating 4-cyanophenol, as a major product are reported to be the main observed processes [39]. Wheat plants enhanced uptake/degradation of methyl parathion, p-nitrophenol and hydroquinone in unsterilized soil by $64.85 \%, 94.7 \%$ and $55.8 \%$ respectively. Methyl parathion hydrolyzes to p-nitrophenol, which is further metabolized to hydroquinone with nitrite release The enzyme p-nitrophenol 4-hydroxylase is active as evidenced by release of nitrite by leaf and root extracts and also by the appearance of hydroquinone in the reaction mixture [16]. Data also in Figures 2 and 3 clear role Plantago major L. in phytoremediation of cyanophos and degradation products in water.

\section{Conclusions}

The use of plants to detoxify contaminated water is a potentially cost-effective alternative to traditional remediation technologies. From the results of this study, it can be ended that the existence of plants increased the removal $t_{1 / 2}$ of cyanophos in water system. Plantago major L. is able to take up cyanophos from water by roots as well as by leaves, so Plantago major L. may be used for phytoremediation of water contaminated with cyanophos insecticide.

\section{Competing interests}

The authors declare that they have no competing interests.

\section{Authors' contributions}

This search individually not shared by one of the researchers. I have made substantial contributions to conception and design, or acquisition of data, or analysis and interpretation of data; 2) I have been involved in drafting the manuscript or revising it critically for important intellectual content; and 3) I have given final approval of the version to be published.

\section{Acknowledgements}

The author is most grateful to the laboratory staff of pesticides analysis and environmental pollution Laboratory, Plant Production Department, Faculty of Technology and Development, Zagazig University, Zagazig, Egypt for their collaboration in this research.

Received: 4 October 2012 Accepted: 14 January 2014 Published: 21 January 2014

\section{References}

1. Mullie W, Diallo A, Gadji B, Ndiaye M: Environmental hazards of mobile ground spraying with cyanophos and fenthion for Quelea control in Senegal. Ecotoxicol Environ Saf 1999, 43:1-10.

2. Tomlin C: The e- pesticide Manual. A world Compendium. 13 2004th edition. United kingdom: British Crop Protection Council: Farniham, surey; 2004:184. 3. Bruggers RL, Elliott CCH: quelea, Africa1s Bird Pest. Oxford: Oxford University Press; 1989. 
4. Floesser-Mueller $\mathrm{H}$, Swack W: Photochemistry of organophosphorus insecticides. Rev Environ Contam Toxicol 2001, 172:129-228.

5. Chiba M, Shlgeru K, Izuru Y: Metabolism of cyanox and surecide in bean plants and degradation in soil. J Pesticide Sci 1976, 1:179-191.

6. Kiso Y, Sugiura Y, Kitao T, Nishimura K: Effects of hydrophobicity and molecular size onrejection of aromatic pesticides with nanofiltration membranes. J Mem Sci 2001, 92:1-10.

7. Rahman MA, Hasegawa H: Aquatic arsenic: Phytoremediation using floating macrophytes. Chemosphere 2011, 83:633-646.

8. Yadamari T, Kalyan Y, Gangadhar B, Ramakrishna N: Biosorption of malathion from aqueous solutions using herbal leaves powder. AJAC 2011, 2:37-45.

9. Susarla S, Medina VF, McCutcheon SC: Phytoremediation: an ecological solution to organic chemical contamination. Ecol Eng 2002, 18:647-658.

10. McCutcheon SC, Schnoor JL: Phytoremediation, Transformation and Control of Contaminants. Hoboken, New Jersey: John Wiley and Sons; 2003:1-58.

11. Romeh A: Phytoremediation of water and soil contaminated with imidacloprid pesticide by plantago major, L. Int J Phytoremediation 2010, 12:188-199.

12. Prasertsup $P$, Naiyanan A: Removal of chlorpyrifos by water lettuce (Pistia stratiotes I.) and duckweed (Lemna minor I.). Int J Phytoremediation 2011 13:383-395.

13. Byrne FJ, Toscano NC: Uptake and persistence of imidacloprid in grapevines treated by chemigation. Crop Prot 2006, 25:831-834.

14. Cheng S, Jin X, Huiping X, Liping Z, Zhenbin W: Phytoremediation of triazophos by canna indicalinn. in a hydroponic system. Int $J$ Phytoremediation 2007, 9:453-463.

15. Romeh AA, Hendawi MY: Chlorpyrifos insecticide uptake by plantain from polluted water and soil. Environ Chem Lett 2013, 11:163-170.

16. Khan NU, Bhavya V, Nazeeb I, Paddu KS: Phytoremediation using an indigenous crop plant (wheat): the uptake of methyl parathion and metabolism of p-nitrophenol. Indian J Sci Technol 2011, 4:1661-1667.

17. Wang Q, Wei Z, Cui. Bo X: Phytoremediation of atrazine by three emergent hydrophytes in a hydroponic system. Water Sci Technol 2012, 66:282-1288.

18. Sharifa AA, Neoh $Y L$, Iswadi Ml, Khairul $O$, Abdul Halim MM, Jamaludin Mohamed A, Hing HL: Effects of methanol, ethanol and aqueous extract of plantago major on gram positive bacteria, gram negative bacteria and yeast. Ann Microsc 2008, 8:42-44.

19. Ahmaruzzaman MD: Adsorption of phenolic compounds on low-cost adsorbents: a review. Adv Colloid Interface Sci 2008, 143:48-67.

20. Felsot A, Dahm A: Sorption of organophosphorus and carbamate insecticides by soil. J Agric Foods Chem 1979, 27:557-563.

21. Tebbutt THY: Principles of Water Quality Control. 3rd edition. Oxford, England: Pergamon Press; 1991:219-220.

22. Wang W: Toxicity tests of aquatic pollutants by using common duckweed. Environ Poll 1986, 11:1-14.

23. EL-Sheamy MK, Hussein MZ, El-Sheak AA, Khater AA: Residue behavior of certain organophosphorus and Carbamate insecticides in water and fish. Egypt J App/ Sci 1991, 6:94-102.

24. Luke MA, Froberg JE, Doose GM, Masumato HT: Improved multiresidue gas chromatographic determination of orgonophosphorus, orgononitrogen and orgonohalogene pesticides in procedure, using flame photometric and electrolytic conductivity detectors. Journal of AOAC 1981, 64:1187-1195.

25. Zaalok A, Sherif A: Combined effect of applied equipment and formulation of pesticide on spray and dust drift in relation to harmful effects for some non-target organisms. Agric Biol J N Am 2011, 2:1059-1065.

26. Gomaa EA, Belal MH: Determination of dimethoate residues in some vegetables and cotton plant. Zagazig J Agric Res 1975, 2:215-221.

27. Thomsen V, Schatzlein D, Mercuro D: Limits of detection in spectroscopy. Spectroscopy 2003, 18:112-114

28. Kang F, Dongsheng C, Yanzheng G, Yi Z: Distribution of polycyclic aromatic hydrocarbons in subcellular root tissues of ryegrass (Lolium multiflorum Lam.). BMC Plant Biol 2010, 10:210

29. Mohamed AE, Rashed MN: Assessment of essential and toxic elements in some kinds of vegetables. Ecotoxicol Environ Saf, Environ Res 2003, 55:251-260

30. Ghaly AE, Snow Kamal AM: Kinetics of manganese uptake by wetland plants. American Appl Sci 2008, 5:1415-1423.
31. Naghizadeh A, Nasseri S, Nazmara S: Removal of trichloroethylene from water by adsorption on to multiwall carbon nanotubes. Iran J Environ Health Sci Eng 2011, 8:317-324.

32. Rengaraj S, Seuny H, Sivabalan MR: Agricultural solid waste for the removal of organics: adsorption of phenol from water and wastewater by Palm seed coat activated carbon. Waste Manag 2002, 22:543-548.

33. Mahvi AH: Application of agricultural fibers in pollution removal from aqueous solution. Int J Environ Sci, Tech 2008, 5:275-285.

34. Hiller E, Fargas A, Zemanova L, Barta M: Influence of wheat Ash on the MCPA immobilization in agricultural soils. Bull Environ Contam Toxicol 2008, 81:285-288.

35. Ofomaja AE: Kinetic study and sorption mechanism of methylene blue and methyl violet onto mansonia wood sawdust. Chem Eng J 2008, 143:85-95.

36. Senthilkumaar S, Krishna SK, Kalaamani P, Subburamaan CV, Ganapathi N: Adsorption of organophosphorous pesticide from aqueous solution using "waste" jute fiber carbon. Mod App/ Sci 2010, 4:67-83.

37. Derbalaha AS, Belalb EB: Biodegradation kinetics of cymoxanil in aquatic system. Chem Ecol 2008, 24:169-180.

38. Al-Makkawy HK, Madbouly MD: Persistence and accumulation of some organic insecticides in Nile water and fish. Resour Conserv Recycl 1999, 27:105-115.

39. Mikami N, Ohkawa H, Miyamoto J: Photodecomposition of surecide (O-ethyl O-4-cyanophenyl phenylphophonothioate) and Cyanox (O, O-dimethyl O-4-cyanophenyl phosphorothioate). J Pestic Sci 1976, 1:273-281.

40. Azmat $\mathrm{R}$, Haider $\mathrm{S}$, Riaz $\mathrm{M}$ : An inverse relation between $\mathrm{Pb}^{2+}$ and $\mathrm{Ca}^{2+}$ ions accumulation in Phaseolus mungo and Lens culinaris under $\mathrm{Pb}$ stress. Pak J Bot 2009, 41:2289-2295.

41. Turgut C: Uptake and modeling of pesticides by roots and shoots of parrot feather (myriophyllum aquaticum). Environ Sci Pollut Res 2005, 12:342-346.

42. Bouldin JL, Farris JL, Moore MT, Smith SJ, Cooper M: Hydroponic uptake of atrazine and lambda-cyhalothrin in Juncus effusus and Ludwigia peploides. Chemosphere 2006, 65:1049-1057

43. Wang MJ, Jones KC: Behaviour and fate of chlorobenzenes (CBs) introduced into soil-plant systems by sewage sludge application: a review. Chemosphere 1994, 28:1325-1360.

44. Chefetz B: Sorption of phenathrene and atrazine by plant cuticular fractions. Environ Toxicol Chem 2003, 22(10):2492-2498.

45. Karthikeyan R, Lawrence D, Larry E, Kassim A, Peter A, Philip L, Stacy L, Asil A: Potential for plant-based remediation of pesticide-contaminated soil and water using nontarget plants such as trees, shrubs, and grasses. Crit Rev Plant Sci 2004, 23:91-101.

46. Chuluun B, Janjit I, Jae Seong R: Phytoremediation of organophosphorus and organochlorine pesticides by acorus gramineus. Environ Eng Res 2009, $14: 226-236$

47. Ibrahim S, Abdel Lateef M, Khalifa H, Abdel Monem A: Phytoremediation of atrazine-contaminated soil using Zea mays (maize). Ann Agric Sci 2013, 58:69-75.

48. Rankins A, Shaw R, Boyette M: Perennial grass filter strips for reducing herbicide losses in runoff. Weed Sci 2001, 49:647-651.

49. Angier T, McCarty W, Rice $P$, Bialek $K$ : Influence of a riparian wetland on nitrate and herbicides exported from an agricultural field. J Agric Food Chem 2002, 50:4424-4429.

50. Zhao S, Arthur L, Coats R: The use of native prairie grasses to degrade atrazine and metolachlor in soil. In Environmental Fate and Effects of Pesticides. Edited by Coats JR, Yamamoto H. Washington, DC: ACS Symposium Series 853, ACS; 2003:157-167

51. Kodaka R, Sugano T, Katagi T, Takimoto Y: Comparative metabolism of organophosphorus pesticides in water-sediment systems. J Pestic Sci 2003, 28:175-182.

doi:10.1186/2052-336X-12-38

Cite this article as: Romeh: Phytoremediation of cyanophos insecticide by Plantago major L. in water. Journal of Environmental Health Science \& Engineering 2014 12:38 